\title{
Reply from the Gulf
}

SIR-The leading article "Beyond the trouble in the Gulf" (Nature 346, 683; 1990 ) theorizes about the alleged failings of economic and social policies in the Gulf countries on a basis of misunderstanding and even unfamiliarity with the facts.

The article offers three arguments why peace will not come to the Middle East even after the current crisis is over. First, it says the Gulf countries have squandered their oil wealth and failed to share it with less fortunate countries. "The bulk of what other oil-producing states earn [other than Iraq] is routinely sent back to the purchasers of oil, usually in the form of credits controlled by named individuals".

To examine these arguments, let us take the example of Saudi Arabia. No other country has shared its wealth so generously with the poor, developing countries.

\section{Safety first}

SIR - The dilemma posed by issues such as the safety and economics of bovine somatotropin (bovine growth hormone) (Nature 347, 11; 1990) was best expressed by that master of the two-liner, Alexander Pope, a hundred years before the ludditelike solution ascribed by Lesser to opponents of the hormone:

In words, as fashions, the same rule will

Alike fantastic if too new or old:

Be not the first on whom the new are tried,

Nor yet the last to lay the old aside.

- Alexander Pope,

Essay on Criticism.

Part II, line 133 [1711]

Physicians have told me of a medical aphorism based evidently on the Pope dictum, or perhaps on harsh reality: don't be the first to try a new drug or the last to give it up.

PO Box 16057 ,

Burton L. ApPLETON

Alexandria,

Virginia 22302, USA

\section{Noted scientists}

SIR-I should like to add to the list of scientific figures to have appeared on banknotes (Nature 347, 415; 1990) Erwin Schrödinger on the Austrian 1,000schilling note, and - although not on a par with the other scientists - Sigmund Freud on the 50-schilling note and Eugen Böhm-Bawerk (1851-1914), an Austrian political economist, co-founder of the marginal utility school, on the 100schilling note. All three notes are currently in circulation.

Mariahilfer Str. 133,

FRIEDRICH KATSCHER

\section{A-1150 Vienna, Austria}

Saudi Arabia provided aid worth US\$59,700 million between 1973 and 1989. This figure works out to 5.45 per cent of gross national product (GNP) which is by far the highest ratio of aid to GNP in the world. Out of this figure, fully 57 per cent or $\$ 34,380$ million was given in the form of grants. More than 70 developing countries have benefited from Saudi aid, of which 38 are in Africa, 25 in Asia and 7 in other developing countries. Saudi Arabia is second only to the United States in terms of the total value of aid given in the period 1973-89. So much for the argument that Saudi Arabia, among others, has not shared its oil-wealth with less fortunate countries.

The second argument is even more absurd. It claims that these countries have neglected the development of social infrastructure, specifically education. "The oil-producers of the Middle East seem not to have turned their minds to creating a first-rate university somewhere." Again, the author has absolutely no idea of the tremendous progress made in Saudi Arabia in education and the social sectors over the past 15 years. The King Fahd University of Petroleum and Minerals in Dhahran is universally recognized as among the best of its kind in the world. It is not for nothing that its Saudi graduates are progressively taking over the oil sector in Saudi Arabia. But more than this, 2.8 million male and female students were enrolled in various educational institutions in 1990 compared with 573,000 students in 1970. The number of schools went up from 2,949 in 1970 to 16,476 in 1990 .

In higher education, 122,000 male and female students were enrolled in 78 institutions of higher learning in 1990 compared with a figure of 6,942 students in 1970. The total number of teachers in higher education was 9,950 in 1988 , which gives a student-teacher ratio of 11.5 , surely among the best in the world.

Finally, the third argument truly reflects a lack of knowledge of the region. The authors says: "There has been too little investment in industrial enterprise, even in the downstream processing of oil itself". The truth is exactly the opposite.

Again, to take the example of Saudi Arabia, the entire economic philosophy of Saudi planning is to diversify the economy away from the production and export of crude oil alone. The successful breaking away from the 'monoculture' of oil can be seen from the fact that in 1975 , crude oil and natural gas contributed 75 per cent to GDP, while it contributed only 23 per cent to GDP in 1987. This is a remarkable achievement indeed. And it is the result of using the oil wealth to enlarge the industrial base of the country.

Establishing advanced industrial cities in Saudi Arabia started in 1970, and much of it already developed indicates a substantial commitment towards industrial development. Jubail and Yanbu were created from scratch in what is commonly recognized as one of the greatest planning, engineering and construction projects of all time. Oil refineries and petrochemical industries are today fully operational there. The petrochemical industries, most of which are already being expanded, command roughly 5-7 per cent of the world's installed capacity in bulk petrochemicals.

Hand-in-hand with the process of domestic industrialization, Saudi Arabia has successfully embarked on a course of downstream integration in the global oil market. The joint venture with Texaco, called Star Enterprise, is already a model of cooperation and integration. It commands roughly 11,000 retail outlets and three refineries, and assures the company of up to 600,000 barrels a day of Saudi crude. This programme of downstream is bound to grow in the future in the interests of pure commercial viability as well as the reciprocal security of supply and demand in the oil world. Besides, the Saudi economic Offset Program established in the mid-1980s requires the successful bidders for the sale of defence equipment to invest in partnership with the Saudi investors an amount equal to 25-30 per cent of the total programme contract. It was further required that the investment be in hightech industries.

More than all of this, Saudi Arabia has succeeded in creating what is perhaps the ultimate welfare state in the world. Stateof-the-art physical infrastructure is already in place. Health-care and education are free and widely available. Housing is subsidized and most Saudis own their own houses. Electricity, water and telecommunications are all abundantly supplied to meet the needs of the country.

\section{Ministry of Planning,} HUSSEIN A. SEIINI

\section{Riyadh, Saudi Arabia}

SIR-The leading article "Beyond the troubles in the Gulf" (Nature 346, 683; 1990) well describes the causes of the current trouble in the Middle East. The unequal distribution of oil revenues, the lack of constructive development in the oil-producing states, and the corruption of the ruling governments have definitely contributed to the current conflict, but another major cause seems to be overlooked: the Palestinian-Israeli conflict. I cannot imagine a peaceful Middle East for as long as Israel continues to occupy Palestinian, Syrian and Lebanese land and as long as the five million Palestinians remain living in exile.

M. D. ABOUZAHRA

PO Box 1087

APO San Francisco 96555, USA 